\title{
Religions in progress or regress: Inner Strength matters, from the Buddhist perspective
}

\author{
Dr. Poey Tiang Peow \\ Lecturer in Mandarin at the Centre for Languages and Pre-university Academic Development, \\ International Islamic University Malaysia
}

\begin{abstract}
Religions in general offer remedies to aching minds and therefore humans seek relief for their problems in life. Spirituality is always a matter of concern and people who follow different religions are constantly searching for it. Man becomes helpless in extreme difficulties and it is quite natural that religions play significant roles in human lives. It is mainly because the complexities in life are being increased day by day and to encounter this people take refuge in spirituality.

All religions offer some sort of solutions and so they are relevant among the followers. Therefore, they play decisive roles in the life of individuals. Religions are not only sets of beliefs, but they also provide guidelines to the people's life. They become ideals of people, strengthening their inner values and morals in life. But increased institutionalization of religions and some of the practices and customs may distract people from them. Involvement of religions in politics in certain areas in the globe has also created a negative attitude among the common people.

Communal tensions, terrorism, atrocities and even war are caused because of the differences of the opinions among followers of different religions. There might be strong reasons why people are deviated from religions and the practices.

In order to address those issues, Buddhism as a philosophy answers the basic problems of life, as it explains the causes of conflicts and the needs for the enlightenment. In this paper, I attempt to show how the Inner Strength of individuals can be a very crucial aspect that can help man to achieve wisdom in all aspect, and in so doing we argue that new outcome and religious education would be necessary to help the society as well as the individuals to that end. This paper also argues that the development of mutual understanding and a peaceful survival of mankind necessitate religious education and interaction between various ideologies.
\end{abstract}

Keywords: Religion; Inner Strength; Religious Education; Religious Pluralism; Buddhism

\section{Academic Discipline and Sub-Disciplines}

Education; Religious Studies

\section{SUBJECT CLASSIFICATION}

Library of Congress Classification

\section{TYPE (METHOD/APPROACH)}

Literary Analysis; Survey used Focus Group Discussion

\section{Council for Innovative Research}

Peer Review Research Publishing System

Journal: International Journal of Management \& Information Technology

Vol. 7, No. 1

editor@cirworld.com

www.cirworld.com, member.cirworld.com 


\section{INTRODUCTION}

In Buddhism, "Inner Strength" refers to mind. As stated in the Buddhist Mahayana sutras: All phenomena are manifested by the mind. Our mind can divide into three types which are described as follows:

1. There is the mind of flesh inside our body, it is called the heart, and it is given by our parents through birth.

2. There is the mind of comprehension that reacts to different situations. It tells the difference between the good and evil, good and bad fortune. In Buddhism, the sensory organ composed its existence.

3. There is the mind of truth that is eternal and constant. In Buddhism, the Enlightenment comes through the realization of the Self-Nature True Mind or One True God. Thus the Self-Nature True Mind, Buddha, and sentient beings, while three, are in fact one. They have the same Self-Nature True Mind and no different from one another. Sentient beings and Buddhas appear interchangeably, their thoughts meshing with one another's. ${ }^{1}$

In Tiantai Buddhism, our mind consists of Ten Dharma Realms' seeds. According to Venerable Master Hua, ${ }^{2}$ the Ten Dharma Realms are Buddha, Bodhisattva, Pratyekabuddha, Arhat, Celestials, Asura, Human, Animals, Hungry Ghost, and Hell. The Dharma Realms of Buddha, Bodhisattva, Pratyekabuddha, and Arhat also called The Four Sagely Dharma Realms. The Celestials, Asura, Human, Animals, Hungry Ghost, and Hell also called The Six Common Dharma Realms.

It is also said that the Buddha Dharma Realm has the retinue of Buddhas; the Bodhisattva Dharma Realm has the retinue of Bodhisattvas; the Dharma Realm of Pratyekabuddha has its retinue of Pratyekabuddha; and the Dharma Realm of Arhat has its retinue of Arhat.

In the Six Common Dharma Realms, the Dharma Realm of the Celestials or gods, with its retinue of gods. There are many different kinds of gods which they aren't all the same. There is also the Dharma Realm of Asuras with its retinue of Asuras. Then there's the Dharma Realm of people, and they are also of many different kinds. Those are the Three Wholesome Paths: Celestials or gods, humans, and Asuras.

Then there are the Three Evil Paths: the hells, hungry ghosts, and animals. The Realm of animals has its own retinue which is made up of many different kinds of animals. Then there's the category of hungry ghosts with its own different particular kinds of hungry ghosts. Lastly there is the realm of hell-beings, and its hundreds of thousands of different varieties of hell-beings. Each one of those categories is further divided into subcategories, and each sub-category has many different kinds of beings within it. ${ }^{3}$

The Ten Dharma Realms are, in fact, created by the mind, because the mind has the capacity to create such massive things. Our minds produce thoughts with which individuals are capable of creating different things in this world. Master Hua quotes the Buddha as saying:

If one wishes to know the Buddhas of the three periods of time, one should contemplate the nature of the Dharma Realm:

\section{Everything is made from mind alone. ${ }^{4}$}

Tiantai Buddhism taught the principle of Three Thousand Realms in a Single Thought Moment based on the Lotus Sutra. The number Three Thousand is derived from the Ten Dharma Realms, multiplied by ten due to each Dharma Realm has the mutual possession of the Ten Dharma Realms, which gives One Hundred. In other words, Lotus Sutra stated that the life at each moment is endowed with the Ten Dharma Realms. At the same time, each of the Ten Dharma Realms is endowed with all the Ten Dharma Realms, so that an entity of life actually possesses One Hundred Dharma Realms. The One Hundred Dharma Realms multiplied by Ten Factors based on the Lotus Sutra which gives One Thousand Dharma Realms. The One Thousand Dharma Realms multiplied by three which are the Three Realms of Existence which are Self, Other, and Environment; which gives Three Thousand Dharma Realms. ${ }^{5}$ The Ten Factors based on the Lotus Sutra are to define the fundamental reality of life which described as follows: appearance; nature; entity; power; influence; internal cause; relation; latent effect; manifest effect; and consistency from beginning to the end. ${ }^{6}$ By viewing a given state of affairs with the perspective of the Ten Factors, it can become easier to identify the root of suffering and change the situation so it leads to attain the different levels of Buddhahood or Perfect Enlightenment.

The Three Thousand Dharma Realms of existence are all possessed by life in a single moment. If there is no life, that is the end of the matter. But if there is the slightest bit of life, it contains all the Three Thousand Dharma Realms. The founder of Tiantai tradition of Buddhism in China is Master Zhiyi (538-597 CE). Master Zhiyi is famous for being the first in

\footnotetext{
${ }^{1}$ TiangPeow, Poey, The Importance of Inter-Religious Dialogue to Promote World Peace: A BuddhistPerspective, Uniprints Marketing Sdn Bhd, Kuala Lumpur, 2009, p. 43.

${ }^{2}$ Dharma Talk by Venerable Master Hua, translated by BhikshuHengTso, "THE TEN DHARMA REALMS", retrieved on 7 July 2013 from http://www.drbachinese.org/vbs/publish/152/vbs152p017e.pdf.

${ }^{3}$ Dharma Talk by Venerable Master Hua, translated by BhikshuHengTso, "THE TEN DHARMA REALMS", retrieved on 7 July 2013 from http://www.drbachinese.org/vbs/publish/152/vbs152p017e.pdf.

${ }^{4}$ Ibid.

${ }^{5}$ Refer to http://en.wikipedia.org/wiki/Zhiyi.
}

${ }^{6}$ Ming yang, Shi, Introduction to Buddhism, Chinese Version, Shanghai Yuan Ming Lecture Hall Editorial Board, China, 1990, p. 335 
the history of Chinese Buddhism to elaborate a complete, critical and systematic classification of the Buddhist teachings. $\mathrm{He}$ is also regarded as the first major figure to make a significant break from the Indian tradition, to form an indigenous Chinese system. ${ }^{7}$

Maitreya Bodhisattva in the Púsàchùtāijīng (菩萨处胎经) mentioned that A Single Thought Moment equally to 1600 trillion vibrations in a second, which refers to the rapid arising and ceasing of mind. Both physical and mental phenomena are appearing together, which is derived from our minds. ${ }^{8}$ MaitreyaBodhisattva said, if we can let go A Single Thought Moment through Samadhi, we will attain and restore to the Buddhahood or Self-Nature True Mind, due to Self-Nature True Mind neitherarises nor ceases, it is able to create everything without confrontation. Common Chinese terms for Samadhi include the transliterations sanmei (三昧) and sanmodi (三摩地 or 三摩提), as well as the translation of the term literally as chanding (禅定). In Buddhism, Samadhi is referred to the mental concentration, composing the mind or concentration of the mind.

Sakyamuni Buddha in the Surangama Sutra clearly stated increasing greed in our mind causes floods; anger causes fire, such as volcanic eruptions and the rise in temperature; ignorance causes disasters from the wind; arrogance causes earthquakes; disbelief causes friability of earth. In fact, greed, anger, ignorance, arrogance and disbelief are the five roots of the natural disasters as well as the diseases of human body.

The German physicist, Max Planck (1858-1947 CE) mentioned that all matters originate and exist only by virtue of a force which brings the particle of an atom to vibration and holds this most minute solar system of the atom together. We must assume behind this force the existence of a conscious and intelligent mind. This mind is the matrix of all matter. ${ }^{9}$ Therefore, matter is accumulated from units of consciousness which refer to the rapid arising and ceasing of thoughts. There is no matter that goes without consciousness. Both physical and mental phenomena derive from our thoughts. Once our thought ceases, the universe disappears and at the same time our Self-Nature True Mind instantly emerges. Our SelfNature True Mind is neither physical nor spiritual. It is true purity, true goodness, compassion, impartiality, and universal love. Self-Nature True Mind neither arises nor ceases. It is all-knowing and able to create everything without confrontation. In various religions, normally refer the Self-Nature True Mind as the true creator of the universe, the One True God.

In Buddhism, Inner Strength also refers to Bodhi Mind. The word Bodhi means enlightened. There are three main stages of Enlightenment: the Enlightenment of Sravakas (Hearers); the Enlightenment of the Pratyekabuddhas (Self-Awakened); and the Enlightenment of the Buddhas. The Enlightenment of the Buddhas is the highest stage of Buddhahood, its transcending those of the Sravakas and Pratyekabuddhas, and is therefore called Supreme Enlightenment or Supreme Bodhi. This Supreme Bodhi Mind contains two principle seeds, Compassion and Wisdom, from which emanates the great undertaking of rescuing oneself and all other sentient beings. ${ }^{10}$ In Buddhism, Buddhahood is the state of Perfect Enlightenment. In other words, Buddhahood also called the Supreme Bodhi Mind or Supreme Enlightenment is the ultimate goal of a cultivator.

For example, the discovery of Inner Strength or inner energy via orthodox Zen-Buddhist practice, for more than 2000 years, reveals a new form of energy other than the physical phenomena. This form of energy is interpreted by ZenBuddhism practitioners as "the radiance of our fundamental nature, the light of wisdom, or the light of eternal life". In ZenBuddhism, fundamental nature means our "true self", in contrast to the physical entity that is our "phantasmal self" due to its finite duration of existence. The ultimate aim of orthodox Zen-Buddhist practice is to attain an eternal state called Buddhahood. The first step toward Buddhahood is to prove the original, true self which is discover and uncover the light of eternal life. This light called the inner energy or inner light ${ }^{11}$.

Sakyamuni Buddha attained the Buddhahood and discovered the eternal of the universe in meditation. The eternal truth comprehends the light of supreme wisdom, the nominal energy, and the natural powers of the true self. Orthodox ZenBuddhism originated when Buddha Sakyamuni transmitted this light of wisdom to the Great Kashiyapa some 2500 years ago. The same path towards Buddhahood was promulgated to mainland China in 527 by Bodhi dharma, the $28^{\text {th }}$ patriarch. The current patriarch is Zen Master Wu Chueh Miao Tien, the $85^{\text {th }}$ patriarch of the orthodox Zen-Buddhism Sect since the Great Kashiyapa.

Although the Inner Strength or inner energy is an inconceivable, supernatural power, one can explore the inner energy by transcending the physiological (fifth), mental (sixth), subconscious (seventh) and Alaya (eighth) conscious states. The human life system in this state may be interpreted as follows: One shuts off his physical and mental sensors, disables the message transmission from the outside world, and is finally freed from the interference of the subconscious. In the physical world, the human life system lives in the domain of physical, mental and even subconscious activities.

\footnotetext{
${ }^{7}$ Refer to http://en.wikipedia.org/wiki/Zhiyi.

${ }^{8}$ http://www.buddhist-canon.com, qiánlóngdàzàngjīng (乾隆大藏经), Vol.45, p.628-742.

${ }^{9}$ Refer to http://en.wikipedia.org/wiki/Max_Planck.

${ }^{10}$ Thichthien Tam, Buddhism of Wisdom and faith, The Corporate Body of the Buddha Educational Foundation, Taiwan, 1994, p.29-30.

${ }^{11}$ Pei-Chen Lo, Ming-Liang Huang and Kang-Ming Chang, EEG Alpha Blocking Correlated with Perception of Inner Light During Zen Meditation, The American Journal of Chinese Medicine, Vol. 31, No.4, 629-642, World Scientific Publishing Company \& Institute for Advanced Research in Asian Science and Medicine, p. 630, 2003.
} 
Nevertheless, a message originating or conveyed in this domain is to our true self, behaves like the dark cloud covering the brilliance of the sunlight. ${ }^{12}$

Itamar and Jerrold states:

"The alpha rhythm of the electroencephalogram, defined as those wave forms with a frequency of between 8 and 13 per second, depends for its presence on a state of resting wakefulness. When attention is focused on a stimulus, whether this be visual, auditory, tactile, or cognitive, the alpha waves normally disappear or are markedly reduced in amplitude. This phenomenon is generally called alpha blocking, but is also referred to as arousal, activation, and desynchronization." 13

Perceiving the inner light, as stated by the practitioners, makes them feel they are being blessed by the Inner Strength or inner energy of true self. For example, during the blessing period, significant alpha blocking was observed in experimental subjects who had been practicing meditation for years in preparation for being in resonance with the inner light. ${ }^{14}$

The word Buddha is a Sanskrit word. When translated it means "wisdom and enlightenment". Buddha includes essential as well as functional meanings. In essence, Buddha means wisdom. In application or function, it means enlightenment.

Buddha has a three-fold body. There is an aspect of Essence or Dharma-kaya or Body of Dharma; there is an aspect of Sambhoga-kaya or Body of Recompense or Potentiality; and there is an aspect of Nirmana-kaya of Body of Manifestation. Dharma-kaya is the substance of the Self-Nature True Mind. In the aspect of Essence or Body of e, Eternal Buddha has no shape or colour, and since Buddha has no shape or colour, He comes from nowhere and there is nowhere for Him to go. Like the blue sky, He arches over everything, and since He is all things, He lacks nothing. He does not exist because people think He exists; neither does He disappear because people forget Him. Buddha transcends every conceivable direction of human thought. Buddha's body in this aspect fills every corner of the universe; it reaches everywhere, it exists forever. ${ }^{15}$ Eternal Buddhas dwell in the Land of Eternally Quiescent Light.

Sambhoga-kaya signifies that the nature of Buddha, the merging of both Compassion and Wisdom, which is imageless spirit, manifests itself through the symbols of birth and death, through the symbols of vow-making, training and revealing His sacred name, in order to lead all people to salvation. Compassion is the Essence of this body and in its spirit Buddha uses all devices to emancipate all those who are ready for emancipation.

Nirmana-kaya signifies that, in order to complete the relief of Buddha of Potentiality, Buddha appeared in the world in bodily form and showed the people, according to their natures and capacities, the aspects of the birth, renunciation of this world and attainment of Enlightenment. In order to lead the people, Buddha in this body uses every means such as illness and death.

The form of Buddha is originally one Dharma-kaya, but as the nature of people varies, Buddha's form appears differently. Although the form of Buddha varies according to the different desires, deeds and abilities of people, Buddha is concerned only with the truth of the Dharma. ${ }^{16}$ Though Buddha has three-fold body, His spirit and purposes are one that is to save all sentient beings.

Buddhism is the Buddha's teachings. In regards to time, it encompasses the past, present and future. In regards to space, it talks about everything: from our living environment all the way to infinite worlds. Thus, Buddhism is also a teaching of wisdom which includes the understanding of life and universe.

The principle of Buddhism is to break through all superstitions and delusions. It is to resolve delusion to attain happiness and enlightenment, to eliminate suffering to gain serenity and purity of mind. Resolving delusion to attain enlightenment is the cause and eliminating suffering to attain happiness and purity is the effect. Only through resolving superstition and delusion, can enlightenment be attained. This is the objective of the Buddha's teaching. This wisdom will enable all beings to differentiate true from false, proper form improper, right from wrong, and good from bad. It can help us to establish a dynamic and caring attitude toward life and our surroundings. Buddhism enables us to obtain true and ultimate benefits by creating fulfilling lives, happy families, harmonious societies, prosperous nations, and a peaceful world. These are the objectives of the Buddha's teachings for our world now. Therefore, we can say that Buddhism is an education that will enable us to attain truth, virtue, beauty, wisdom, and genuine eternal happiness.

In tradition, Buddha Dharma consists of two traditions, the Northern and Southern Schools. The Southern Tradition teaches everyday practical realities and emphasis swift emancipation for oneself, producing the attainment of Arhats or also called Self-Awakened Buddhas. The Northern Tradition refers to Mahayana or Great Vehicle, teaches lofty, allencompassing truths and stresses the goal of liberating all sentient beings, leading to the complete enlightenment of the

\footnotetext{
${ }^{12}$ Pei-Chen Lo, Ming-Liang Huang and Kang-Ming Chang, EEG Alpha Blocking Correlated with Perception of Inner Light During Zen Meditation, The American Journal of Chinese Medicine, Vol. 31, No.4, 629-642, World Scientific Publishing Company \& Institute for Advanced Research in Asian Science and Medicine, p. 630, 2003.

${ }^{13}$ ItamarSalamon\&Jerrold Post, "Alpha Blocking and Schizophrenia,” in Jama Psychiatry, vol 13, no. 4, 1965, p. 367374.

${ }^{14}$ Ibid,p.629.

${ }^{15}$ Society for the Promotion of Buddhism, The Teaching of Buddha, Kosaido Printing Co., Ltd, Japan, 1966, p. 50-52.

${ }^{16}$ Ibid, p.54.
} 
Tathagata. The Amitabha Buddha recitation method is a Mahayana teaching and therefore is not only directed towards the goal of self-enlightenment, but stresses the enlightenment of others at the same time.

When Buddhism spread to China, it evolved through the teachings of Patriarchs, into ten schools. Among them, two schools which belong to the Southern Tradition are Satysiddhi School and the Abhidharma School. Since the Chinese people did not correspond to the Southern Tradition, they used Taoism and Confucianism to replace it.So within a short period of time, these two Schools faded away. The other eight schools are all Mahayana which belong to the Northern Tradition are Tiantai School; Avatamsaka School; Three Sastras Schools; Yogacara or Dhamalaksana School; Vinaya or Discipline School; Zen School; Esoteric School; and Pure Land School. ${ }^{17}$ Based on the SukhavatiVyuha (Pure Land Sutra), this lineage was founded in 402 C.E. by Master Hui Yuan (332-416 C.E). The Pure Land lineage held that the spiritual quality of the world has been in decline since its height during the lifetime of the Buddha and taught followers to cultivate through prayer and devotion a sincere intent to be reborn in the heavenly paradise of the Amitabha Buddha.

In history record, Master Hui Yuan's group, comprised of both monastic and lay followers, was called the White Lotus Society, and a vow taken by Master Hui Yuan and the 123 members of this group is often celebrated as the origin of the Pure Land School in China. The 123 members all practice the Amitabha Buddha Recitation Method, finally the 123 members all successfully reborn in the Western Pure Land. ${ }^{18}$ In fact, the most important point for separating the Northern and Southern traditions to do with the Mind, not the Dharma. If we were to use the Thevarada teachings as an expedient, to teach and transform people and lead them to Buddhahood, this would be Mahayana. Based on this, when cultivators recite the Amitabha Buddha's name, they also emphasize of the development of the Supreme Bodhi Mind.

\section{THE METHODOLOGY TO RESTORE THE INNER STRENGTH FROM BUDDHISM}

In Buddhism, Inner Strength can be attained and restored through learning and practicing from the Buddha's teachings through the scriptures which are highlighted as follows:

\section{Four Noble Truths}

We use Four Noble Truths to attain and restore our Inner Strength. The Four Noble Truths are as follows:

(1) The truth of suffering; (2) The truth of the origin of suffering; (3) The truth of cessation of suffering; (4) The truth of the path to the cessation of suffering. Sakyamuni Buddha explained the eight causes of suffering in his Truth of suffering.

The human condition has always entailed countless sufferings, as exemplified by the eight types enumerated below: Suffering of birth; old age; disease; death; due to separation from loved one; due to meeting with the uncongenial; due to unfulfilled wishes; due to the raging skandas or aggregates, the five skandas refer to form, feeling, perception, volition, and consciousness. ${ }^{19}$

\section{Noble Eightfold Path}

The way leading to the cessation of suffering is The Noble Eightfold Path, which is described as follows:

(1) Right understanding or right views; (2) Right aspiration or right intention; (3) Right speech; (4) Right action; (5) Right livelihood; (6) Right effort; (7) Right mindfulness; (8) Right concentration.

\section{Three Learning}

(1) Abiding by the precepts or self-discipline; (2) Deep concentration or Samadhi; (3) Wisdom. People who abide by precepts do not break rules, they won't go astray. Therefore, we have to keep the precepts in mind and be mindfulness mot to violate them in our everyday life. So, precepts serve to guard our mind and body. If we keep the precepts in mind, we will not engage in wrong actions or be led astray. We'll have a wholesome stability of mind called Samadhi. When our mind is upright naturally we won't deviate or stray onto a wrong path. So, with precepts and Samadhi, wisdom will arise. We'll know what we should and shouldn't do, what words we should and shouldn't say, what thoughts we should and shouldn't have what to do and what not to do. Our thinking will be correct and upright. So, we need to practice precepts, Samadhi, and wisdom. Then, we won't do wrong things which means our mind will be without afflictions. When there are no afflictions, our mind will naturally become like a clear mirror that can reflect all images accurately.

\section{Three Blessings or Conditions}

There are eleven principles of the Three Blessings which are described as follows:

\section{The First Blessings include:}

\section{(1) Being filial to our parents}

To be a virtuous person, the first and most fundamental principle is being filial towards our parent. Filial piety has profound meanings in Buddhism. It means to take care of parents physically, mentally, and to fulfil their wishes. To further extend

\footnotetext{
${ }^{17}$ Yulingbo, Introduction Buddhism to Elites, Buddha Education Foundation, Taiwan, 1997.

${ }^{18}$ Huili, Pure Land Saints and Sages Record. GaoxiongWenshu Lecturer Hall, Taiwan, 2002, p.85.

${ }^{19}$ ThichthienTam, Buddhism of Wisdom and Faith, The Corporate Body of the Buddha Educational Foundation, Taiwan, 1994, p.14.
} 
and enhance our respect and care for our parents, we have compassion for all beings in this world. As stated in Precept Sutra that all men are my father, all women are my mother. This is the broadening of our mind of filial piety so that it encompasses all beings in the universe, in the past, present, and future.

\section{(2) Being respectful to our teachers and elders}

We have to pay respect to our teachers and elders for their teachings and guidance in our life. In Buddhism, Sakyamuni Buddha is our original teacher. Buddhists pay respect to an image of Sakyamuni Buddha because the image as a representation of our original teacher.

\section{(3) Being compassionate and not killing any living beings}

We have to be compassionate, and help others. Compassion includes not killing any living being.

\section{(4) Following the Ten Good Conducts}

Sakyamuni Buddha groups the Ten Good Conducts to three major categories which are physical, verbal and mental. Physically, we are prohibited from killing, stealing, and committing sexual misconduct. There are four verbal good conducts which are no lying or cheating; no abusive language or make rude remarks; no bearing tales or do not talk about others behind their back for this sows discord among people, and seductive words or the words sound very sweet and enticing but often conceal bad intentions. There are three mental good conducts which are no greed, no anger and no ignorance. In Buddhism, if we can fulfil the requirements of the First Blessings, we are considered good men and good women among the humans and in the celestials' realm.

\section{The Second Blessings include:}

\section{(5) Taking the Three Refuges}

To be a Buddhist practitioner, we have to take the Three Refuges of the Buddha, Dharma and Sangha. Taking refuge in the Buddha means being awaked and not deluded; Taking refuge in the Dharma means having proper viewpoints; Taking refuge in the Sangha means being pure and not polluted. These are the Triple Jewels of Self-Nature that the Buddha taught us for our practice which are awakening, proper viewpoints and purity. The Triple Jewels are also represented by images of Buddhas, sutras, and monks and nuns. They are to remind us of the need to return and rely on the Triple Jewels of our Self-Nature.

\section{(6) Abiding by precepts, laws and customs}

We have to abide the precepts, laws and customs. Of all the precepts, the most important are the basic Five Precepts. The Five Precepts are no killing, committing sexual misconduct, lying, and taking intoxicants. Sakyamuni Buddha told us that if we can abide by the precepts, laws and customs, we will have a tranquil body and mind which will allow us to be free from worries and fear.

\section{(7) Behaving in a proper and dignified manner}

Behaving in a proper and dignified manner means that we act appropriately for the circumstances we are in. We act from the heart of sincerity and respect for all beings, animate and inanimate, to accord with social etiquette. In Theravada Buddhism, the criteria of good men and good women are required to fulfil the First and Second Blessings. Theravada Buddhism or Early Buddhism or Southern Buddhism propagated after Asoka in the south of India, Sri Lanka, Thailand, Cambodia, Myanmar, etc. The scriptures preserved in these countries are written in the Pali language and belong to the Theravada teachings. Practitioners aim at attaining the state of Arhat.

\section{The Third Blessings includes:}

\section{(8) Generating the Bodhi Mind}

Chinese Buddhists primarily practice Mahayana Buddhism, and wish to develop the Bodhi Mind which is the awakened mind that is genuinely free from delusions. It is the awakened mind that realizes this world is filled with misery and suffering. It is the compassionate and sincere mind, with every thought to attain realization for self and others.

\section{(9) Deeply believing in the Law of Cause and Effect}

In general, we know that good causes will result in good effects and that bad causes will result in bad effects. However, Flower Adornment Sutra stated that the Ten-Grounds Maha-Bodhisattvas and the level of Equal Enlightenment MahaBodhisattva, all practised the Buddha Name Chanting method. Thus, chanting the Amitabha Buddha's name is the cause and attaining Buddhahood is the effect.

\section{(10) Reciting and upholding the Mahayana sutras}

Reciting and upholding the Mahayana sutras, which help us to understand the true reality of life and the universe. With this understanding, we will know the proper way to think and behave as well as the appropriate method to use. We will benefit from the sutra if we truly accord with the teachings of the sutra.

\section{(11) Encouraging others on the path of Enlightenment}

Encouraging others on the path of Enlightenment is to encourage and help others to understand and practice Buddhism because Buddhism is a most virtuous and perfect education directed by the Shayamuni Buddha towards all sentient 
beings in the universe. In regards to time, it encompasses the past, present and future. In regards to space, it encompasses everything from our daily lives to the infinite universe. Buddhism is an education of the wisdom and understanding of life and the universe. By fulfilling all the principles in the Three Blessings, from practicing filial piety for parents to encouraging others on the path to enlightenment, we will become the good men and good women as stated in the Mahayana sutras. ${ }^{20}$

\section{FAITH, VOWS AND PRACTICE}

In Pure Land Buddhism, Faith, Vows and Practice are the three cornerstones to restore our Inner Strength in order to attain Buddhahood. Faith means faith in Amitabha Buddha's vow to rescue all who recite His name, as well as faith in one's own Self-Nature True Mind, which is intrinsically the same as His. In other words, to recite the Amitabha Buddha's name is to recite the Self-Nature True Mind. Vows are the determination to be reborn in the Western Pure Land which is inside in one's Self-Nature True Mind, so as to be in the position to save oneself and others. Practice generally means reciting the Amitabha Buddha's name to the point where one's Self-Nature True Mind and that of Amitabha Buddha are in unison, for example to the point of single-mindedness, Samadhi and wisdom are then achieved. ${ }^{21}$

From the historical perspectives, the true intention of Sakyamuni Buddha, when he appeared in the world to preach the Dharma and rescue sentient beings, was for all beings to escape the cycle of Birth and Death and attain Buddhahood or Perfect Enlightenment immediately. However, due to sentient beings were all of differing capacities and thus could not entirely meet Sakyamuni Buddha's transcendental expectations, the All-Compassionate Being resorted to one expedient teaching after another, all of them adapted to the individual capacities of sentient beings.

To those of the highest capacities, the Great Sage taught the path of the Buddhas, showing them the Self-Nature True Mind directly so that they might attain Buddhahood in one lifetime, for example in the case of Sudhana in the Avatamsaka Sutra; the Dragon Princess in the Lotus Sutra, and the sixth patriarch Master Hui Neng(638-713) in China during dynasty Tang. Master Hui Neng is one of the most beloved teachers in Zen Buddhism; he attained Buddhahood on his age 24. Upon attained the Buddhahood, he described the characteristics of Buddhahood or Self-Nature True Mind or Essence of Mind as follows:

\section{Who would have thought that the Essence of Mind is intrinsically pure! \\ Who would have thought that the Essence of Mind is intrinsically free from becoming or annihilation! \\ Who would have thought that the Essence of Mind is intrinsically self-sufficient! \\ Who would have thought that the Essence of Mind is intrinsically free from change! \\ Who would have thought that all things are the manifestation of the Essence of Mind! ${ }^{22}$}

Thus, we know that the characteristics of Buddhahood or Self-Nature True Mind or Essence of Mind are intrinsically pure; intrinsically free from change; intrinsically free from becoming or annihilation; intrinsically self-sufficient; intrinsically free from change; and all things are the manifestation of the Essence of Mind!

To those of more modest capacities, the Buddha taught the Bodhisattva, Pratyekabuddha and Arhat paths, so that they might reach Buddhahood through step-by-step cultivation. To those of still lower capacities, the Buddha taught the Five Precepts and the Ten Virtues. The Five Precepts refer to not to kill; steal; engage in illicit sex; take intoxicants; and lie. The Ten Virtues refer to not to: killing; stealing; sexual misconduct; lying; slander; coarse language; empty chatter; covetousness; angry speech; wrong views.

However, in the midst of this Dharma-Ending Age, there are very few good spiritual advisors, while the capacities of sentient beings are limited. It is difficult enough to find someone who is awakened to the Way, not to mention one who has truly attained Perfect Enlightenment! Thus, knowing that sentient beings would find it extremely difficult to achieve liberation by relying on self-power and deep cultivation alone, Sakyamuni Buddha taught, in addition to other methods, the special approach of Amitabha's Western Pure Land.

With this method, as long as their Faith and Vows are true and earnest, even those who have committed the Five Grave Offences or the Ten Evil Acts, may, on the verge of death, when the marks of the hells appear, follow the advice of a good spiritual advisor and recite the Amitabha Buddha's name to ten times. Then, thanks to the compassionate power of Amitabha Buddha, even they will be received and guided to the Western Pure Land, not to mention those who practice wholesome deeds and do not commit transgressions! ${ }^{23}$ Five Grave Offences refer to killing one's father; one's mother; or an Arhat; causing dissension within the Sangha; causing the Buddhas to bleed. The Ten Evil Acts refer to killing; stealing;

\footnotetext{
${ }^{20}$ TiangPeow, Poey, The Importance of Inter-Religious Dialogue to Promote World Peace: A Buddhist Perspective, Uniprints Marketing Sdn Bhd, Kuala Lumpur, 2009, p. 29-34.

${ }^{21}$ Thichthien Tam, Pure-Land Zen and ZenPureLand, letters from Patriarch Yin Kuang, International Buddhist Monastic Institute, USA, 1993, p.11.

${ }^{22}$ The Corporate Body of the Buddha Educational Foundation, The Sutra of Hui Neng, Sutra Spoken by the $6{ }^{\text {th }}$ Patriarch on the High Seat of the Treasure of the Law, H.K. Buddhist Book Distributor Press, 2007, p. 20.

${ }^{23}$ Thichthien Tam, Pure-Land Zen and ZenPureLand, letters from Patriarch Yin Kuang, International Buddhist Monastic Institute, USA, 1993, p.57.
} 
sexual misconduct; lying; slander; coarse language; empty chatter; covetousness; angry speech; wrong views, these are opposite of the Ten Virtues.

\section{PRACTICE OF CHANTING}

The Pure land Buddhism Buddhists repeat the phrase Amituofo (In Sanskrit is Amitabha) for a few minutes a day to one or more hours a day depending on the practitioners' preference. The Pure land Buddhism Buddhists believe that by chanting Amituofo, we can access to our Buddha-nature or the Self-Nature True Mind or Buddhahood. We can then bring out strong life force or Inner Strength or positive inner qualities such as wisdom, compassion, joy, confidence, appreciation, etc. Amituofo or Amitabha Buddha means the Buddha of Infinite Light and Infinite Life.

Amitabha Buddha is omniscient and all-seeing within and outside of his realm and is especially concerned with knowing human activity, so that he helps remove ignorance; but he does not judge or punish. Amitabha Buddha is the creator of his realm which is Western Pure Land, the source of all good in it. Sakyamuni Buddha in the Sutra Rebirth According to One's Vows had mentioned that he extols only the Western Pure Land and emphasis on the sentient beings have to focus their minds on a single realm. If the sentient beings meditate on all Buddhas, the scope of attention will be too broad, their minds will be lost and scattered and they will find concentration difficult to attain.

Thus, the necessity of reciting the Amitabha Buddha's name until single-mindedness is the basic requirement during one's lifetime in order to achieve rebirth in the Western Pure Land. Furthermore, seeking the virtues of one Buddha is the same as seeking the virtues of all Buddhas because all Buddhas have one common Dharma Nature. That is why to focus on Amitabha Buddha is to focus on all Buddhas; to be born in the Western Pure Land is to be born in all Buddhas' Pure Lands. Besides, we also must know that a Buddha Land is the area of a Buddha's spiritual influence.

Beings in a particular Buddha Land may benefit from that Buddha's spiritual guidance and accumulated merit. In Mahayana Buddhism, there are an infinite number of Buddhas, each with his own Buddha Land. One must through cultivation, and fulfilling the standard of entry requirements of the Buddha be born into the Buddha Land. Thus, the Buddhist of Mahayana Buddhism, normally seeking to achieve the stages of realization from the One True God is the rebirth of Amitabha Buddha's Western Pure Land, also namely as Land of Ultimate Bliss, and Western Paradise.

It is ruled over by Amitabha Buddha, who created it by his karmic merit. In Western Pure Land, all beings cleave to the truth of the teaching until their final entry into Nirvana. It is the sphere of pure spiritual activity. Those born there are awakened to the ultimate reality, and compassion that spontaneously arises in them. In other words, having become Bodhisattvas, they participate in Amitabha Buddha's endless work of delivering beings from delusions, afflictions and sufferings. Their supreme happiness is hearing the teaching proclaimed by Amitabha Buddha especially at the OceanWide Lotus Assembly.

Amitabha Buddha dwells in the centre of the land and is accompanied by the two great Bodhisattvas, the associates of Amitabha Buddha which are Mahasthamaprapta Bodhisattva and Avalokitesvara Bodhisattva (Guanyin). The Lotus Assembly represents the gathering of Amitabha Buddha, the Bodhisattvas, the saints and sages and all other superior beings in the Western Pure Land. This Assembly is "Ocean-Wide" as the participants are infinite in number which spread as far and wide as the multitude of oceans in the cosmos or namely Dharma Realm.

\section{THEORETICAL FRAMEWORK}

Durkheim did not believe that a religious belief system could provide a sufficiently powerful or flexible system of belief to address the complex patterns of social interaction and differentiation experienced by modern society. He believes the scientific resources of sociology can be used to identify and bolster the sense of social solidarity nascent in the individualist ethic. He argued that sociology should help to develop a new secular morality by showing how it could be promoted in schools, workplaces and other organizations in which people come together from different walks of life. ${ }^{24}$

\section{Religious Education in Amitabha Buddhist Society Malaysia}

From the theoretical framework of Durkheim (1858-1917), to develop a new secular morality education based on structural functionalism to address the complex patterns of social interaction and differentiation experienced by modern society is urgently needed. This can begin with the religious education. For example, in 2012, the Amitabha Buddhist Society Malaysia (ABSM) had conducted 27 children classes with 435 students; 13 teenagers' classes with 257 students; and 4 adult or parents classes with 275 students. ${ }^{25}$ The total numbers of the students are 967.

The students are learning the courses of Dizigui (Confucianism), Ten Good Virtuous Sutra (Buddhism) , LaoziTaishanganyingpian (Taoism); Infinite Life Sutra; and etc. In traditional, the three courses of Dizigui (Confucianism), Ten Good Virtuous Sutra (Buddhism), LaoziTaishanganyingpian (Taoism) are the basic teachings and core moral values of traditional Chinese culture. The ABSM started its religious education class since 2002. From here, we know that if we continued to promote the new secular morality education, especially religious education, the religion will be greatly progress.

\section{Group Discussion}

\footnotetext{
${ }^{24}$ Pip Jones, Liz Bradbury \& Shaun Le Boutillier, Introducing Social Theory, Second Edition, Polity Press, UK, 2011, p.70.

${ }^{25}$ Refer to the Record Minutes of General Assembly on $13^{\text {th }}$ May 2012 of Amitabha Buddhist Society Malaysia.
} 
On $30^{\text {th }}$ Jun 2013, the researcher had used the method of a focus group discussion on the topic of Inner Strength. The group discussion involved a total of 16 teenagers, age from 18 to 23; and 4 adults for nearly an hour. The major outcomes of the four major questions as discussed are listed as below:

(1)From Buddhist perspectives, what is the Inner Strength?

The Inner Strength is described as mind; thoughts; energy vibration; and all phenomena are manifested by the mind.

(2)What are the characteristics of the Inner Strength?

The characteristics of the Inner Strength are described as purity; equality; enlightenment; appearances are created by our own minds; circumstances are changed by our minds.

(3) How to restore the Inner Strength?

The Inner Strength can restore through: purity of mind; recite the name of Amitabha Buddha; think of Amitabha Buddha; deep concentration or Samadhi; compassion; increase the attainment levels of Samadhi; the development of Bodhi Mind, which is to attain Buddhahood for the benefit of all sentient beings.

(4)How the Inner Strength influence the religion's progress or regress?

The Inner Strength influence the religion's progress or regress through: developing religious education; the disciples group together to recite the name of Amitabha Buddha and practice the 48 vows of Amitabha Buddha; the quality of religious teacher; and the disciples' mind to practice and fulfil the religion's objectives.

True religious education and interaction between various ideologies is a necessity to develop understanding and for the healthy survival of mankind

We have to acquire a true understanding of our own religion's teaching and scriptures in order to deliver the true teachings of our own faiths. Besides, we are also encouraged to study and understand other religions' scriptures. This certainly will help us to deliver and contribute to the new practical ideas and thoughts through the inter-religious dialogue to promote world peace. These are described as follows:

(1) The religious education helps to achieve lasting world peace, thus we must really understand the teachings of our own faiths

Religious people need to delve deeply into the religious texts of their respective faiths, so as to truly understand those teachings and precepts and to put those teachings into practice in their daily lives. Thus, the cordiality and equality among the diverse religions will be achieved. Indeed, the religious conflicts and animosity that we see today are largely due to the fact that many religious people, while fervent, nevertheless do not really understand the teachings of their own faiths and, thus, lack wisdom. They become blind followers, falling prey to people who have ulterior motives. Ultimately this either results in or contributes to violence and conflicts.

Thus, the inter-religious dialogue plays a great important role to promote religious education in order to achieve world peace. In Buddhism, Sakyamuni Buddha said: "Delusion is the root cause of suffering, while enlightenment is the source of happiness." Thus, the conflict between one's delusion from one's habits and the awakened state of one's true nature is really the root cause.

The conflicts arise because one's thoughts, speech, and behaviour do not accord with the innate virtuousness of one's nature. When one's thoughts and behaviour do not accord with one's nature, conflict will arise. In fact, the origin of conflict is greed. Therefore, in the teaching of Sakyamuni Buddha, greed, anger and ignorance are considered the root causes of conflict and are called the Three Poisons. The most fundamental among Three Poisons is greed because one's greed is the source for any form of selfish gain.

\section{(2)We are encouraged to understand the teachings of other faiths}

We are encouraged to understand the teachings of other faiths through seminar, conference, symposium, brainstorming session, etc. in order to create a better understanding in inter-religious dialogue to promote world peace. We have to learn, understand, practice and implement the central conviction of 'one-humanity' and many faiths. For example:

(1) One should be filial, uphold utmost sincerity, and be loyal and trustworthy. (The Buddha Speaks of the Infinite Life Sutra of Adornment, Purity, Equality and Enlightenment of the Mahayana School, Chapter25; Buddhism).

(2) Honour your father and mother, so that you may livelong in the land the LORD your God is giving you. (Bible, New International Version, Exodus 20: 12; Christianity).

(3) Whoever honours his father will receive joy from his own children and be heard when he prays? Whoever gives glory to his mother prepares a treasure for him. (Bible, Catholic Pastoral Edition, Sirach3:4-5; Catholicism).

(4) Worship Allah and join none with Him in worship, and do 'good' to parents, kinsfolk, orphans, the poor, the neighbour who is near of kin, the neighbour who is a stranger, the companion by your side, the wayfarer you meet, and those slaves whom your right hands possess. Verily, Allah does not like those who are 'proud and boastful'. (Quran, 4:36; Islam).

(5) There should be no error in the duties towards the gods and manes. Let your mother be a goddess unto you. Let your father be a god unto you. Let your teacher be a god unto you. Let your guest be a god unto you. The works that is not blameworthy are to be resorted to, but not the others. (Taittiriya-Upanishad, I-xi-2-4; Hinduism). 
(6) Be loyal to your superiors, filial to your parents, respectful to your elders and siblings, and sincere to your friends. (Lord Superior Wen Chang Tract of the Quiet Way; Taoism).

(7) The purpose of the One True God in manifesting Himself is to summon all mankind to truthfulness and sincerity, to piety and trustworthiness, to resignation and submissiveness to the Will of God, to forbearance and kindliness, to uprightness and wisdom. His object is to array every man with the mantle of a saintly character, and to adorn him with the ornament of holy and goodly deeds. (Gleanings from the Writings of Baha'u'llah 299; Baha'i).

(8) The father of a righteous man has great joy; he who has a wise son delights in him. May your father and mother be glad; may she who gave your birth rejoice. (Bible, New International Version, Proverbs 23:24-25; Judaism).

(9) Make wisdom thy mother, contentment thy father, and truthfulness thy brother. These are thine good relations. (Siri Guru Granth Sahib, page 151; Sikhism).

(10) When we have established our character by the practice of the filial course, so as to make our name famous in future ages and thereby glorify our parents, this is the end of filial piety. (The Doctrine of Filial Piety, Chapter I : The Scope and Meaning of the Treatise; Confucianism). ${ }^{26}$

Thus, the essence of moral and virtuous teachings of the saints and sages basically use the virtues such as filial piety, loyalty, trustworthiness, etc. to guide the public's own thoughts, actions, and provide a way to stabilize the society and offer the underlying basis of education for all people.

\section{(3) We must have the macro views to improve the moral standards of all people}

Today, moral dilemma and the current never-ending ethical crisis issues facing us in our societies. In view of this, we need to have the macro views to improve the moral standards of all people through the teaching of saints and sages' education of religions to promote world peace. The true meaning of the saints and sages' education that we discuss today differs from the skill-based teaching of modern learning institutions which are emphasis on the purity, goodness, sincerity and loving-kindness that each person intrinsically possesses and continually sustains and enhances these qualities.

The saints and sages' education can be categorized into moral education, virtuous education, causality education and religious education. The teachings of moral education are to promote the understanding of the true relationships between human beings. For example, loving relationship between parents and children, district responsibility between husbands and wives, loyalty and fairness between leaders and followers, order between seniors and juniors, and trust between friends.

The teachings of virtues education are to promote compassion, equality, harmony, respect and cooperation towards all people, matters, objects, and for all people to return from bad habits to the intrinsic kindness that all people possess. Besides, the teachings of causality education are to emphasize on the cause and effect of continuity that are extended from past to present and present to future. Faiths lead to understanding; understanding leads to humbly seeking evidence and realization; thus such teaching leads to true benefit and enjoyment in the future.

The teachings of religious education need to be modern and in accordance with local customs; be tolerant and live in harmony with all factions and religions; use concentration and wisdom to resolve confrontations, ambiguities, doubts and conflicts; promote and enhance intrinsic compassion and love to attain harmony among all people and treat all with equality; and provide a haven for all beings in our society to learn the ultimate education that will lead to happiness and fulfilment. Besides, the religious education should help us to understand the relationship between human and beings of different dimensions, and to understand the relationship between human and the natural environment.

\section{(4) We must have vows as a momentum to develop the inter-religious dialogue to promote world peace}

Making a vow to help the world citizens from sufferings is a crucial element for interfaith-religious dialogue to promote world peace. Thus, we must have vows for helping and benefiting all mankind as a momentum to develop the interreligious dialogue to promote world peace. In Buddhism, we have the Four Universal Vows of the Buddhas and Bodhisattvas as a great momentum for Buddhist to continue on their cultivation. The Four Universal Vows are listed as follows:

(1) Sentient beings are innumerable; I vow to help them all.

(2) Afflictions are inexhaustible; I vow to end them all.

(3) Ways to practice are boundless; I vow to master them all.

(4) Enlightenment is unsurpassable, I vow to attain it.

Besides, in Mahayana Buddhism, the Ten Great Vows of Universal worthy Bodhisattva as a great momentum to Buddhists. These vows were taught to us by the Sakyamuni Buddha in the Flower Adornment Sutra. The Ten Great Vows of Universal Worthy Bodhisattva are listed as follows:

\section{(1) Paying respect to all Buddhas}

\footnotetext{
${ }^{26}$ TiangPeow, Poey, The Importance of Inter-Religious Dialogue to Promote World Peace: A Buddhist Perspective, Uniprints Marketing Sdn Bhd, Kuala Lumpur, 2009, p. 9-13.
} 
Flower Adornment Sutra mentioned that sentient or insentient, all attain Buddhahood. Thus, all beingsthat have SelfNature True Mind, and all things such as plants and minerals have Dharma-Nature. We treat people, matters and objects with equal respect. This is the virtue of the way of Universal Worthy Bodhisattva.

\section{(2) Praising the Buddhas}

Praising is linked to virtue. Only good characteristic and accepted laws deserve praise. We admire the good but not the bad. Thus, praising the Buddhas apply to nature, paying respect to all Buddhas applies to behaviour.

\section{(3) Making extensive offerings}

Universal Worthy Bodhisattva told us that of all the many kinds of offerings that of the teachings is supreme. However, only Sakyamuni Buddha's teachings can help sentient beings break through confusion and delusion for uncovering the perfect Self-Nature and achieving the Enlightenment.

\section{(4) Repenting misdeeds and karmic obstacles}

Everybody has karmic obstacles. Every thought in a person's mind causes a karmic act, which in turn will certainly results in an obstacle. There are two types of obstacles which are caused by afflictions and knowledge attachment. We create these constantly. Sakyamuni Buddha told us in the Flower Adornment Sutra that all beings have the Buddha's wisdom and virtue but cannot attain them due to their wandering thoughts and attachments. In Mahayana Buddhism, we are reciting the name of Amitabha Buddha that is "Amituofo" in Chinese. We have to repent our misdeeds, thus we also have to make sure that with every thought of "Amituofo", we have the same thought and vow as the Amitabha Buddha, and we need to turn his forty-eight vows into our own in order to get rid of karmic obstacles and transgressions.

\section{(5) Rejoicing in others' merits and virtues}

This vow tells us that we are not only joyful over others' merits and virtues, but to help them accomplish even more. If we are unable to offer assistance, we can at least express our joy and admiration. However, if we are able to offer assistance, then it will be a true fulfilment of this vow. We must remember that helping others is helping ourselves. We would do well to love and tolerate those who exceed us for in this way; we will accomplish the virtue of this vow.

\section{(6) Requesting the Buddhas to teach or turn the Dharma Wheel}

Sakyamuni Buddha's wish is for all sentient beings to hear the truth, practice accordingly and receive the benefits to attain Buddhahood. Thus, we can request the turning of Dharma Wheel, in other words, we invite knowledgeable masters to teach us about the sutras. We will get the greatest good deeds, virtues and merits because it brings the teachings to the world.

\section{(7) Requesting the Buddhas to remain in this world}

If we want to reach enlightenment, we need to request the Buddha to remain in this world. The Sakyamuni Buddha' himself is no longer here but his followers are, be they monks, nuns, or laypeople. Those who are knowledgeable and virtuous can be invited to reside in our town or city to give teachings. In this way, we will be constantly under their guidance.

\section{(8) Following the teachings of the Buddhas at all times}

Although Sakyamuni Buddha no longer resides in this world, we still have his sutras to follow and study. Following the sutras is the highest standard for us in the process of learning and practicing Buddhism.

\section{(9) Accommodating and benefiting all living beings}

For accommodating and benefiting all living beings, we need to look for the right opportunities to try to encourage people to stop committing wrong doings. This will help them to break through delusion and attain enlightenment. However, to do this perfectly, we need to recognize the right way and for this, we need wisdom, expediency and flexibility.

\section{(10) Transferring all merits and virtues universally}

This means transferring all merits and virtues to all the sentient beings in the universe. It means broadening our hearts so that the entire universe becomes one entity. Only when we have reached this state, we can say that we have attained the Great Perfection.

\section{CONCLUSION}

In conclusion, I do hope that we all together to promote and deepen education in ethics, morality and causality for all religious people and citizens in the world. By doing so, the religion will certainly be in good progress, and towards the healthy survival and for a bright future of mankind.

Inner Strength is the ultimate force as far as the human is concerned to get wisdom and to be enlightened. And according to Buddhist philosophy it can be attained if we are prepared to accept it. Your readiness is the most important factor to gain Inner Strength.

\section{REFERENCES}

[1] Huili (2002) Pure Land Saints and Sages Record. Taiwan: Gaoxiong Wenshu Lecturer Hall. 
[2] Pei-Chen Lo, Ming-Liang Huang and Kang-Ming Chang (2003) EEG Alpha Blocking Correlated with Perception of Inner Light During Zen Meditation. The American Journal of Chinese Medicine, Vol. 31, No.4, 629-642. USA: World Scientific Publishing Company \& Institute for Advanced Research in Asian Science and Medicine.

[3] Ming yang, Shi (1990) Introduction to Buddhism. China: Shanghai Yuanming Lecture Hall Editorial Board, China.

[4] Pip Jones, Liz Bradbury \& Shaun Le Boutillier (2011) Introducing Social Theory, Second Edition. UK: Polity Press.

[5] Record Minutes of General Assembly (2012) of Amitabha Buddhist Society Malaysia, Kuala Lumpur on $13^{\text {th }}$ May 2012.

[6] Society for the Promotion of Buddhism (1966) The Teaching of Buddha. Japan: Kosaido Printing Co., Ltd.

[7] The Corporate Body of the Buddha Educational Foundation (2007) The Sutra of Hui Neng, Sutra Spoken by the $6^{\text {th }}$ Patriarch on the High Seat of the Treasure of the Law. H.K: Buddhist Book Distributor Press.

[8] Thichthien Tam (1994) Buddhism of Wisdom and Faith. Taiwan: The Corporate Body of the Buddha Educational Foundation.

[9] Thichthien Tam (1993) Pure-Land Zen and Zen Pure Land, letters from Patriarch Yin Kuang. USA: International Buddhist Monastic Institute.

[10] Tiang Peow, Poey (2009) The Importance of Inter-Religious Dialogue to Promote World Peace: A Buddhist Perspective. Kuala Lumpur: Uniprints Marketing Sdn Bhd.

[11] Yulingbo (1997) Introduction Buddhism to Elites. Tawan: Buddha Education Foundation.

[12] Website

[13] http://en.wikipedia.org/wiki/Max_Planck

[14] http://en.wikipedia.org/wiki/Zhiyi

[15] http://www.drbachinese.org/vbs/publish/152/vbs152p017e.pdf

[16] http://www.buddhist-canon.com, qiánlóngdàzàngjīng (乾隆大藏经)

\section{Author's Biography}

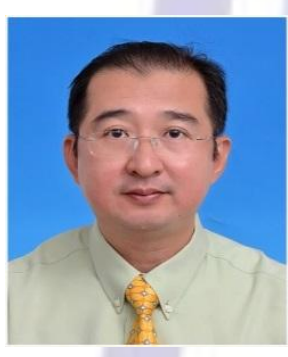

Dr. Poey Tiang Peow is currently a Lecturer in Mandarin at the Centre for Languages and Preuniversity Academic Development, International Islamic University Malaysia.

As a Chinese Language expert and Chinese Buddhism scholar, he has been teaching the language and the teachings of Buddhism for more than 20 years. In the meantime, he is the head of Buddha Education to Amitabha Buddhist Society Malaysia.

He holds a Bachelor of Arts with Honors in Chinese Studies and Malay Studies from University of Malaya. He got his Master of Education in Planning and Administration from University of Malaya. $\mathrm{He}$ also got his Master of Advanced Business and Practice in Business and Administration from University of South Australia. He got his Doctor of Business Administration from United Business Institutes, Belgium.

He had published two books entitled The Importance of Inter-Religious Dialogue to Promote World Peace and the Standards for Being a Good Student and Child, namely Dizigui from the perspectives of Chinese Culture and a number of Research Papers in Chinese Language and Chinese Buddhism. 